\title{
Apparel-based industrialization in the Caribbean Basin: A threadbare garment?
}

\section{Michael Mortimore}

Officer-in-Charge,

Business Strategies and Investments Unit,

ECLAC Division of

Production, Productivity

and Management.
In a world of some two hundred countries, only a relatively few -mainly members of the Organization for Economic Cooperation and Development- can be identified as "winners", that is to say, countries with high and sustained annual per capita incomes in the order of US\$20,000. Among other factors, some of the principal features of winner countries are that: i) they have been through an intense industrialization process, ii) they have projected that process into the international economy in the form of exports of manufactures, and iii) the leading national companies which have exported manufactures have been transformed into transnational corporations (TNCs) in the process. Many developing Asian countries have used the apparel industry as a springboard to deepen their industrialization process, especially by becoming suppliers of "full packages" to international buyers, involving the complete manufacture of apparel according to the designs provided by their international clients. For many Caribbean Basin countries, apparel exports represent their principal link with the international economy. In this case, however, since those exports stem from a low wageexport processing zone-special access package designed to help United States apparel TNCs to compete better in their home market against Asian imports, they do not produce the desired developmental results in the Caribbean. The United States apparel TNCs employ only those factors that allow them to improve the efficiency of their international system of integrated production, which are essentially the low wages paid in the case of the Caribbean Basin. Consequently, instead of deepening the local industrialization process, they truncate it. The exports do not represent the external projection of the local industrialization process, but merely the assembly of imported components. The local apparel companies are not internationalized in the process, but instead have their very existence threatened. Thus, as part of a developmental trajectory, these activities have worn threadbare and need replacement by something better. 


\section{I}

\section{A stylized history of the economic growth of countries}

In a world of some two hundred countries, it can be argued that only about ten or fifteen per cent of them -basically the members of the Organization for Economic Cooperation and Development (OECD) - can be considered to have "made it" in terms of growth and development. They have done so in the sense that they have enjoyed sustained economic growth over many decades, if not centuries, that has allowed them to reach a significant level of per capita income (say, US\$ 20,000 a year). ${ }^{1}$ Figure 1 captures this notion in terms of the "winners' circle" of prominent examples of such successful countries.

The remarkable rise of some nations -in terms of their growth and development- began with the Industrial Revolution in England. It may be noted that the original winners (such as the United Kingdom and the United States) advanced at relatively low annual rates of growth ( $2 \%$ or less) over centuries to reach a level of sustained per capita income that placed them in the winners' circle. Relative latecomers from the old world, like France and Germany, achieved that same goal in less time by growing at a faster rate (about $2.5 \%$ a year). Japan, the first of the Asian nations to achieve winners' status, advanced at about double the rate of the original Anglo-Saxon winners. Other European countries, like Italy and Spain, exceeded the Japanese rate of growth by $50 \%$. East Asian newly industrializing countries (NICs) (such as South Korea, Taiwan, and Hong Kong) are outdoing even these speedsters (5.5\% a year) in approaching their targeted income levels, and China, while far from the goal, is advancing at an even faster rate (7.5\% a year). Within this small group of prominent countries in, or approaching, the winners' circle, latecomers have been able to outperform their predecessors, "making it" in less time by increasing their per capita income at a quicker pace.

What explains the success of these winners? There are undoubtedly numerous factors that influ-

${ }^{1}$ This argument has been developed in much greater detail in Mortimore, 1997.
FIGURE 1

The Winners' Circle: a stylized history of the economic growth of nations

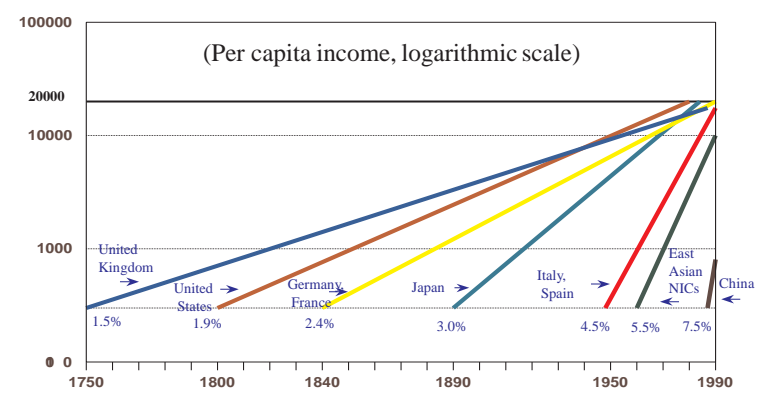

Source: Based on Ramos, J., "Industrial Policy and Competitivenes in Open Economices", CEPAL Review, No. 34, September, 1996.

ence this outcome, but the three central factors taken into account here are:

i) an intense process of industrialization;

ii) the extension of that process to the international market in the form of exports of manufactures;

iii) the creation of national leader companies that develop into world-class global competitors.

A glance at any of the countries in the winners' circle immediately brings to mind some of the principal aspects of their original industrial specialization, the nature of their success in exporting manufactures, and even the names of some of their national champions operating in the international market. Examples of the latter range from United States electrical machinery producers (General Electric and Westinghouse), automobile makers (General Motors and Ford), and computer companies (IBM and Microsoft), to Japanese consumer electronics companies (Matsushita, Sony and Toshiba) and automobile makers (Toyota, Nissan and Honda), and to newcomers from East Asian NICs in the areas of computers (Acer, Hyundai), consumer electronics (Samsung, LG) and motor vehicles (Hyundai, Kia, Daewoo), to name but a few. 


\section{II}

\section{Apparel as a motor of growth}

The apparel industry was an important manufacturing activity and responsible for part of the success of the winner countries' industrialization processes. Indeed, vestiges of that industry can still be encountered in the export profile of those countries. Table 1 shows the 50 most important supplier countries of apparel to the OECD market by import market share during 1980-1995, based on the CAN computer programme developed by ECLAC. ${ }^{2}$ It is an activity of declining importance in these economies as their industrialization processes move into more technologically sophisticated activities, but even so many winner countries are still formidable apparel exporters. Italy is the second most important supplier (even though its OECD market share dropped from $12.89 \%$ to $7.88 \%$ between 1980 and 1995). Germany is fourth (declining from $6.93 \%$ to $3.87 \%$ ), while France is eighth (from $5.37 \%$ to $2.74 \%$ ). The UK is twelfth (from $4.12 \%$ to $2.24 \%$ ) and the United States is fifteenth (from $2.04 \%$ to $1.76 \%$ ). With the exception of Italy, which has specialized more in high fashion (apparel still accounts for a significant proportion of its total exports to the OECD $-7.3 \%$ in 1995), apparel represented less than $2 \%$ of the exports of the other winner countries in 1995. This industry was a motor of growth in the early phases of industrialization.

The apparel industry has been a central element of the export success of the East Asian NICs (especially Hong Kong, Taiwan and South Korea) and the impressive advances of the new Asian Tigers (in particular Indonesia, Thailand, the Philippines and Malaysia) and China. Three of the East Asian NICs are among the top ten apparel suppliers of the OECD:

\footnotetext{
2 The "Competitive Analysis of Nations" (CAN) computer programme of the United Nations Economic Commission for Latin America and the Caribbean (ECLAC) measures the international competitiveness of countries in terms of import market shares (at three digits of the Standard International Trade Classification (SITC, Rev.2)) in five main markets (OECD, Western Europe, North America, Japan, and Latin America). A DOS version on diskettes or a Windows 95 version on CD-ROM can be purchased from ECLAC (contact wperes@eclac.cl).
}

Hong Kong is ranked third (even though its import market share fell from $13.72 \%$ to $7.28 \%$ during 1980 1995), South Korea is fifth (from $9.13 \%$ to $3.82 \%$ ) and Taiwan is in tenth spot (from $6.62 \%$ to $2.45 \%$ ). Except in Hong Kong, where apparel continued to account for more than one-third of total exports (consisting in part of transshipments from China), the importance of apparel in the overall exports of other NICs, such as Korea (dropping from $25.8 \%$ to $9.1 \%$ of total exports) and Taiwan ( $15.4 \%$ to $5.3 \%)$, declined between 1980 and 1995 .

The opposite was taking place in the case of the new Asian Tigers and China in that period. They were becoming more important apparel suppliers and the proportion of apparel in total exports was rising sharply. China, of course, is the new global force in the apparel industry, ranking first with an OECD import market share of $17.57 \%$ in 1995 (up from $2.74 \%$ in 1980). The share of apparel in China's exports to the OECD rose from $10.5 \%$ to $20.4 \%$. The new Asian Tigers have also made their presence felt. Indonesia ranks eleventh (with its OECD import market share for apparel rising from $0.21 \%$ to $2.39 \%$ ), Thailand is thirteenth (from $0.66 \%$ to $2 \%$ ), the Philippines is in sixteenth spot (from $1.41 \%$ to $1.68 \%$ ) and Malaysia is in seventeenth place (rising from $0.48 \%$ to $1.66 \%$ ). The importance of apparel exports in total exports to the OECD has risen substantially for all these countries.

Clearly, the apparel industry has been an important stepping stone for winner countries to get their industrialization processes rolling and to generate solid export streams to the international market. Between 1980 and 1995 the importance of apparel (SITC 84 ) in the total imports of the OECD rose from $2 \%$ to about $3.5 \%$ placing it among the more dynamic industries in international trade. Moreover, the import market share of countries other than OECD ones jumped from $49.3 \%$ to $67.3 \%$ of the total. A good part of that dynamism stemmed from the relocation of apparel production, especially to developing countries, rather than from surges in world demand for apparel products (see Audet, 1996; ILO, 1996, and van Liemt, 1994). 
TABLE 1

The 50 main supplier countries of apparel

(SITC 84) for the OECD market, 1980-1995

\begin{tabular}{|c|c|c|c|c|c|c|c|}
\hline & \multirow{2}{*}{ Country } & \multicolumn{3}{|c|}{ Share of OECD market ${ }^{a}$} & \multicolumn{3}{|c|}{ Apparel as \% of country's total exports } \\
\hline & & 1980 & 1995 & $\%$ change & 1980 & 1995 & $\%$ change \\
\hline 1 & China & 2.74 & 17.57 & 540.64 & 10.52 & 20.36 & 93.63 \\
\hline 2 & Italy & 12.89 & 7.88 & -38.87 & 8.17 & 7.25 & -11.27 \\
\hline 3 & Hong Kong & 13.72 & 7.28 & -46.90 & 37.53 & 35.56 & -5.25 \\
\hline 4 & Germany & 6.93 & 3.87 & -44.19 & 1.78 & 1.50 & -15.35 \\
\hline 5 & South Korea & 9.13 & 3.82 & -58.20 & 25.82 & 9.08 & -64.84 \\
\hline 6 & Turkey & 0.36 & 3.73 & 925.75 & 5.97 & 37.63 & 530.43 \\
\hline 7 & India & 2.09 & 3.32 & 58.79 & 13.60 & 22.67 & 66.66 \\
\hline 8 & France & 5.37 & 2.74 & -48.90 & 2.45 & 1.86 & -24.27 \\
\hline 9 & Portugal & 1.72 & 2.56 & 49.16 & 16.25 & 19.21 & 18.24 \\
\hline 10 & Taiwan ${ }^{b}$ & 6.62 & 2.45 & -62.95 & 15.44 & 5.27 & -65.85 \\
\hline 11 & Indonesia & 0.21 & 2.39 & 1060.49 & 0.35 & 10.51 & 2862.06 \\
\hline 12 & United Kingdom & 4.12 & 2.24 & -45.59 & 1.98 & 1.80 & -9.06 \\
\hline 13 & Thailand & 0.66 & 2.00 & 202.20 & 5.66 & 8.60 & 51.85 \\
\hline 14 & Mexico & 0.77 & 1.85 & 139.21 & 1.59 & 3.76 & 136.82 \\
\hline 15 & United States & 2.04 & 1.76 & -13.75 & 0.50 & 0.71 & 42.25 \\
\hline 16 & Philippines & 1.41 & 1.68 & 19.01 & 9.17 & 17.14 & 86.99 \\
\hline 17 & Malaysia & 0.48 & 1.66 & 244.06 & 1.86 & 5.79 & 210.85 \\
\hline 18 & Tunisia & 1.00 & 1.64 & 65.01 & 20.05 & 51.30 & 155.87 \\
\hline 19 & Poland & 0.80 & 1.59 & 97.94 & 5.75 & 13.89 & 141.72 \\
\hline 20 & Morocco & 0.37 & 1.56 & 324.76 & 6.30 & 37.13 & 489.29 \\
\hline 21 & Netherlands & 1.79 & 1.34 & -25.12 & 1.05 & 1.39 & 33.18 \\
\hline 22 & Dominican Republic & 0.28 & 1.31 & 369.15 & 9.17 & 46.52 & 407.43 \\
\hline 23 & Pakistan & 0.24 & 1.18 & 397.88 & 7.41 & 33.08 & 346.22 \\
\hline 24 & Belgium/Luxembourg & 2.30 & 1.14 & -50.40 & 1.63 & 1.39 & -14.75 \\
\hline 25 & Greece & 2.73 & 1.07 & -60.68 & 24.25 & 21.65 & -10.75 \\
\hline 26 & Romania & 1.01 & 0.92 & -8.84 & 10.50 & 27.00 & 157.10 \\
\hline 27 & Hungary & 0.98 & 0.76 & -21.70 & 12.65 & 10.62 & -16.06 \\
\hline 28 & Canada & 0.45 & 0.68 & 49.90 & 0.26 & 0.54 & 105.56 \\
\hline 29 & Austria & 1.60 & 0.66 & -58.99 & 4.59 & 2.39 & -47.83 \\
\hline 30 & Honduras & 0.04 & 0.62 & 1445.69 & 1.66 & 44.08 & 2557.47 \\
\hline 31 & Spain & 0.77 & 0.61 & -20.63 & 1.83 & 1.26 & -31.12 \\
\hline 32 & Denmark & 0.95 & 0.59 & -38.09 & 2.43 & 2.47 & 1.70 \\
\hline 33 & Costa Rica & 0.12 & 0.58 & 384.03 & 4.65 & 24.49 & 426.57 \\
\hline 34 & Singapore & 1.01 & 0.52 & -49.06 & 5.12 & 1.81 & -64.63 \\
\hline 35 & Guatemala & 0.01 & 0.51 & 3649.02 & 0.47 & 32.54 & 6844.42 \\
\hline 36 & Israel & 0.71 & 0.50 & -29.62 & 6.20 & 5.01 & -19.14 \\
\hline 37 & Jamaica & 0.04 & 0.41 & 861.60 & 1.71 & 34.03 & 1892.24 \\
\hline 38 & Ireland & 0.61 & 0.41 & -32.50 & 2.81 & 1.68 & -40.07 \\
\hline 39 & El Salvador & 0.06 & 0.39 & 539.53 & 2.33 & 46.16 & 1882.51 \\
\hline 40 & Switzerland & 0.82 & 0.38 & -53.87 & 1.05 & 0.78 & -25.90 \\
\hline 41 & Colombia & 0.10 & 0.31 & 204.37 & 1.05 & 5.71 & 443.16 \\
\hline 42 & Egypt & 0.04 & 0.30 & 631.87 & 0.34 & 9.72 & 2799.81 \\
\hline 43 & Bulgaria & 0.17 & 0.27 & 53.71 & 6.96 & 13.38 & 92.24 \\
\hline 44 & Japan & 1.11 & 0.21 & -81.25 & 0.59 & 0.13 & -78.76 \\
\hline 45 & Brazil & 0.25 & 0.21 & -16.27 & 0.63 & 0.96 & 53.79 \\
\hline 46 & South Africa & 0.13 & 0.17 & 33.56 & 0.36 & 1.55 & 329.95 \\
\hline 47 & Peru & 0.03 & 0.14 & 330.53 & 0.42 & 6.40 & 1439.67 \\
\hline 48 & Sweden & 0.61 & 0.14 & -77.24 & 0.86 & 0.33 & -61.39 \\
\hline 49 & Finland & 1.63 & 0.13 & -92.23 & 5.53 & 0.66 & -88.14 \\
\hline \multirow[t]{2}{*}{50} & Australia & 0.04 & 0.10 & 140.89 & 0.10 & 0.51 & 436.62 \\
\hline & Total & 94.05 & 90.14 & & & & \\
\hline
\end{tabular}

Source: Lall and Mortimore, 1997.

${ }^{\text {a }}$ Export values for 1980 are three-year averages; for 1995, two-year averages.

b Taiwan's exports were calculated as residual after other exports were taken into account. The CAN database does not include some large apparel exporters such as Sri Lanka, Bangladesh and Mauritius, each of which exports around US\$ 1.5 to 2 billion of garments per year, about the same level as Morocco. 


\section{III}

\section{The situation of small countries}

Small countries face an especially difficult task in making it to the winners' circle. In scale-based industries, for example, they have difficulty in reaching minimum efficient economic scales of production. They cannot rely on a sufficiently large domestic market -one that will allow them to reach the required levels of production efficiency- in order to develop the kind of operations that will permit them to venture into the international market with the aim of becoming significant competitors. They often start off their industrialization processes in simpler, more labour-intensive industries, such as apparel, and look to trade agreements or economic integration initiatives to expand their markets in order to sustain their industrialization processes and to permit national leader companies to arise and evolve into world players.

This is by no means a trivial observation. Small countries are increasingly becoming the norm in today's world. Eighty-seven countries have populations under five million, 58 have fewer than 2.5 million, and 35 have fewer than 0.5 million. Measured in another way, half of the countries of the world have a smaller population than the United States state of Massachusetts (The Economist, 1998).

The Caribbean Basin is a case in point. Six of the small countries of the Caribbean Basin are among the fifty main suppliers of apparel to the OECD. These small countries have import market shares of less than $1 \%$ each, except for the Dominican Republic, which has more. All are making dramatic advances. The Dominican Republic is in $22^{\text {nd }}$ position (increasing its share from $0.28 \%$ to $1.31 \%$ between 1980 and 1995), Honduras is in 30th place (from $0.04 \%$ to $0.62 \%$ ), Costa Rica reached the $33^{\text {rd }}$ spot (from $0.12 \%$ to $0.58 \%)$, Guatemala is in $35^{\text {th }}$ position $(0.01 \%$ to $0.51 \%$ ), Jamaica reached the $37^{\text {th }}$ spot (from $0.04 \%$ to $0.41 \%$ ), and El Salvador is in $39^{\text {th }}$ place (from $0.06 \%$ to $0.39 \%$ ). In all cases, apparel accounts for between one-quarter (Costa Rica) and about one-half (Dominican Republic, Honduras and El Salvador) of their total exports to the OECD. The apparel industry represents their principal export link with the international economy. However, as we shall see, this is a very peculiar link in the case of the Caribbean Basin.
Significant changes are taking place in the sourcing of OECD imports of apparel. In general, the major "winner" countries of North America and Europe are losing market shares to Asian challengers, but even within Asia, the new major challengers, such as China and the new Asian Tigers, are displacing the East Asian NICs as the sources of such exports (figure 2). Other significant developing country challengers are to be found on the European rim (Turkey, Morocco and Tunisia) and in Latin America (Mexico and the Dominican Republic). As figure 2 suggests, the effect of the North American Free Trade Agreement is to integrate the Mexican industry into the North American one. Apart from Mexico and the Caribbean Basin countries, no other major apparel exporters are found in Latin America.

Except for the dominant Asian suppliers, which are present in all major markets, a very significant regional aspect may be observed in the supply of apparel to the OECD. Figure 3 shows that in the North American market (the United States plus Canada), there are two major apparel-supplying groups of developing countries: those of Asia and those of Latin America (especially Mexico and the Caribbean Basin). China is the principal supplier, followed by Hong Kong, Korea and Mexico. The next level of suppliers are basically Asian (Indonesia, Thailand, Malaysia, the Philippines and India) but also include the Dominican Republic. The outer ring of more minor but rising suppliers consists almost exclusively of Caribbean Basin countries (such as Jamaica, Honduras, Costa Rica, Guatemala and El Salvador), though it also includes Turkey. Latin America is a significant and growing apparel supplier for the North American market.

Other major markets also display regional aspects. In the Western European market the principal developing country suppliers are China, Hong Kong and Turkey. The next level of suppliers come mainly from the European rim (Tunisia, Morocco and Poland) but also include India. The following group of suppliers is a mixture of European rim and Asian suppliers. Latin American and especially Caribbean Basin suppliers are completely absent. The European 
FIGURE 2

Shifts in the regional structure of OECD

(25 countries) apparel imports from 1980 to $1995^{\text {a b }}$

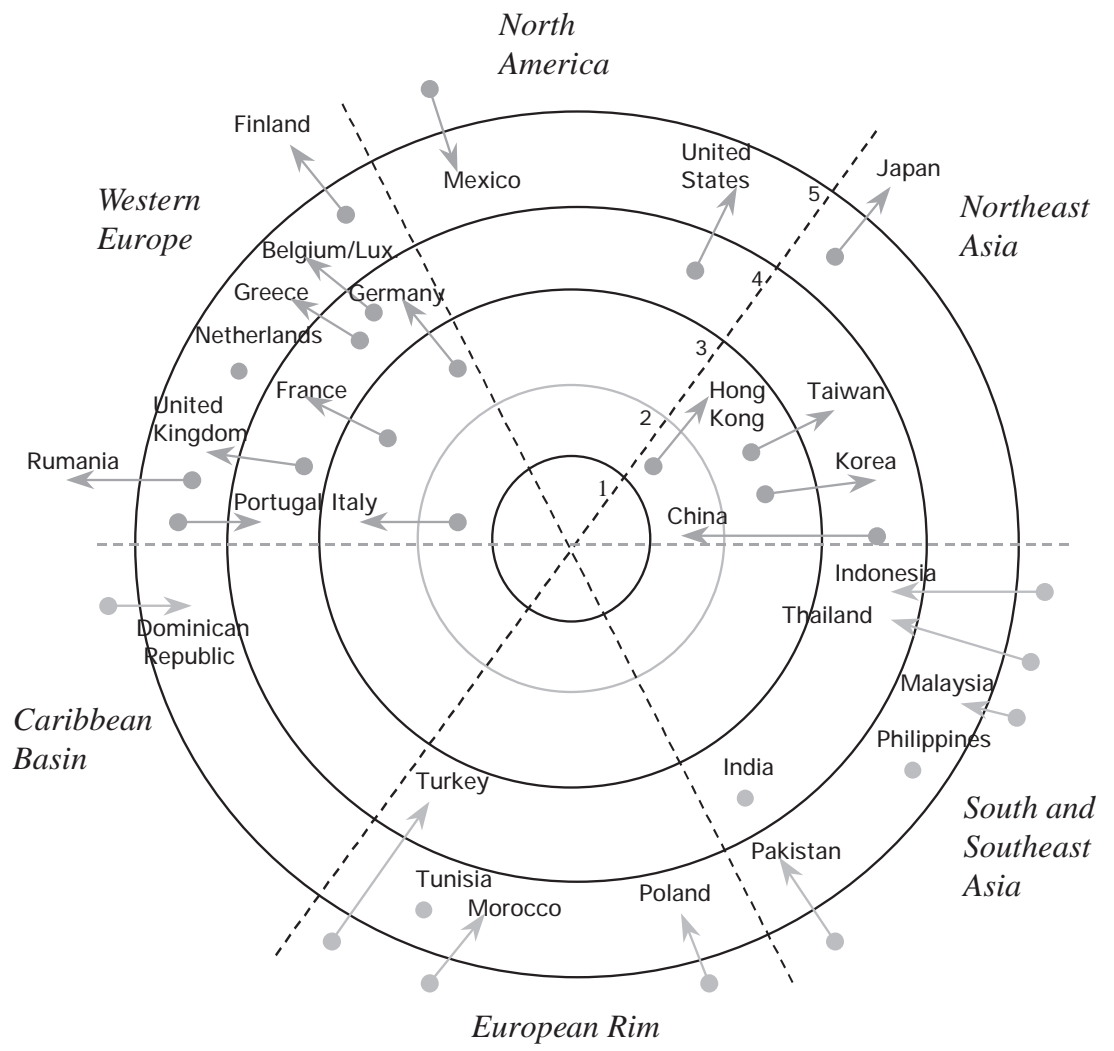

Source: Calculated using the CANPLUS computer programme of UN-ECLAC.

${ }^{a}$ The rings indicate the share of total OECD imports in United States dollars by partner country: 1) > 50\%; 2) 10-49.9\%; 3) 5-9.9\%; 4) $2-4.9 \%$; 5) $1-3.9 \%$. Annual average total value of OECD apparel imports was US\$ 29.4 billion in 1979-1981 and US\$ 120.5 billion in 1994-1995. A minor amount of double counting took place.

${ }^{\mathrm{b}}$ The 1994-1995 position corresponds to the ring where the country's name is located; the 1979-1981 position, if different, is indicated by a circle. The arrows represent the magnitude and direction of change over time. This manner of presenting the relative shifts, using a different data base, first appeared in Gereffi (1997).

rim represents an important and growing supplier base for the Western European market, similar to the relationship between the North American market and its Caribbean Basin suppliers. The Japanese market is supplied basically by a single source country: China. South Korea represents the second most important developing country source of apparel. The next level of developing country suppliers consists of Hong Kong, Thailand, Indonesia and, to a lesser extent, Taiwan. The Japanese market is supplied almost ex- clusively by other Asian countries; the major suppliers from both the European rim and the Caribbean Basin are totally absent.

In other words, there are two predominant realities in the supply of apparel to the countries making up the OECD market. On the one hand, the Asian countries, led by China, the East Asian NICs and the new Asian Tigers, have impressive import market shares in all the major elements of the OECD market: North America, Western Europe and Japan. On the 
FIGURE 3

Shifts in the regional structure of North American (United States and Canada) apparel imports during 1980-1995 ${ }^{\text {ab }}$

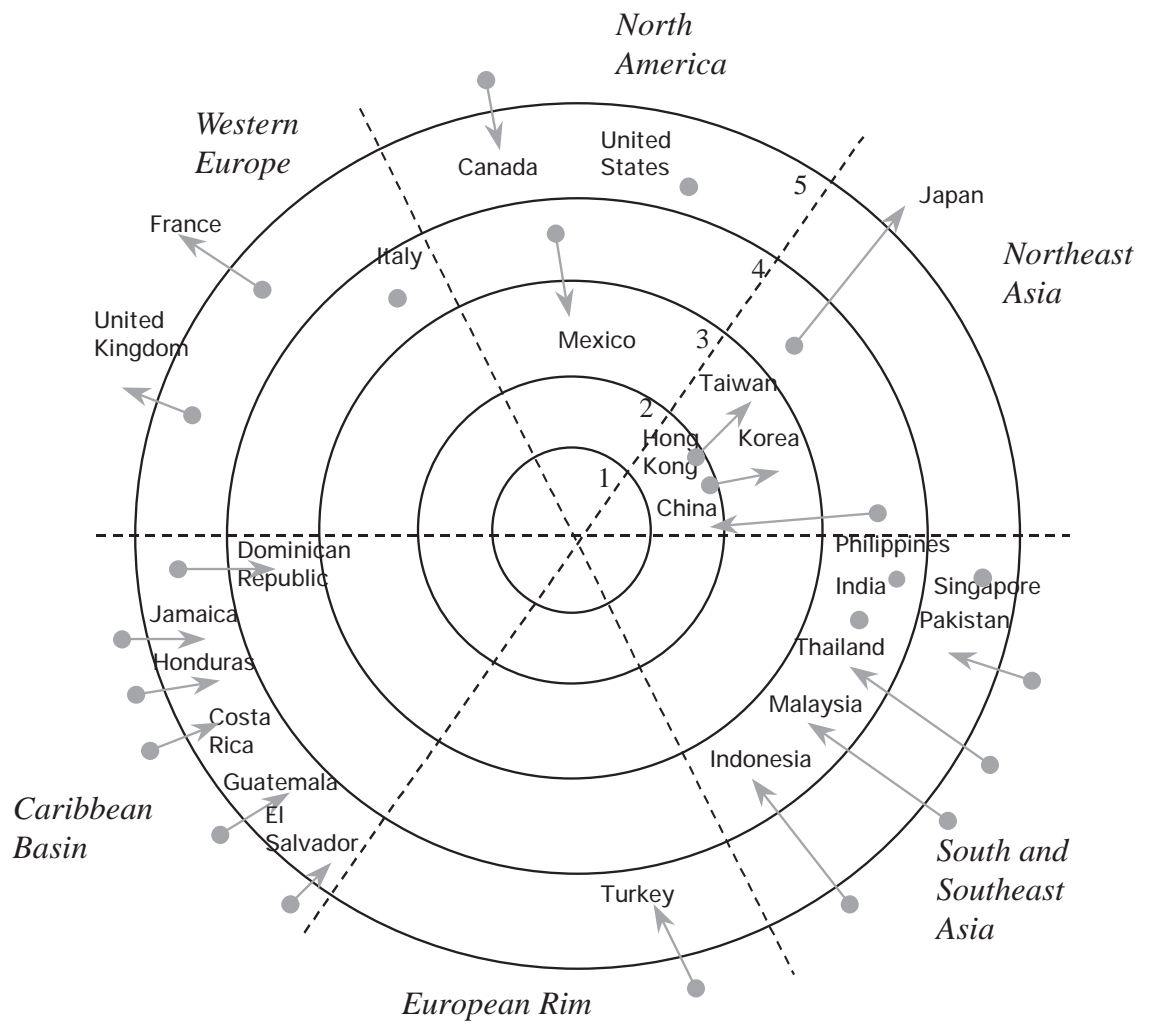

Source: Calculated using the CANPLUS computer program of UN-ECLAC.

a The rings indicate the share of total North American imports in United States dollars by partner country: 1) > 50\%; 2) 10-49.9\%; 3) 5-9.9\%; 4) $4-4.9 \%$; 5) 1- 3.9\%. Total value of North American apparel imports was US\$ 7.9 billion in 1979-1981 and US\$ 42.8 billion in $1994-1995$.

b The 1994-1995 position corresponds to the ring where the country's name is located; the 1979-1981 position, if different, is indicated by a circle. The arrows represent the magnitude and direction of change over time.

other hand, significant and growing import market shares are observed in the case of Mexico and the Caribbean Basin, in the North American market, and the European rim countries, in the Western European market. The Caribbean Basin plays a significant supplier role only in the North American market.

The examples of the Dominican Republic and Costa Rica illustrate this point. Tables 2 and 3 provide the relevant information on the competitive situation of these countries in the North American market. Table 2 indicates that the Dominican Republic has significantly increased its overall share of imports by that market (from $0.28 \%$ to $0.38 \%$ during 1980-1995). That improvement was concentrated in manufactures $(0.13 \%$ to $0.40 \%)$, because in both natural resource-based products $(0.45 \%$ to $0.31 \%)$ and "others" ( $0.82 \%$ to $0.38 \%)$ the Dominican Republic suffered a contraction in its shares of imports by that market. During the 1980-1995 period the structure of Dominican exports to that market was transformed 
TABLE 2

Dominican Republic: Aspects of its international competitiveness in the North American market

\begin{tabular}{|c|c|c|c|c|c|c|}
\hline & & & 1980 & 1985 & 1990 & 1995 \\
\hline I. Share of the North American import market & & & 0.28 & 0.25 & 0.31 & 0.38 \\
\hline Natural resources ${ }^{\mathrm{a}+\mathrm{b}+\mathrm{c}}$ & & & 0.45 & 0.50 & 0.32 & 0.31 \\
\hline Agriculture ${ }^{\mathrm{a}}$ & & & 1.66 & 1.31 & 0.83 & 0.68 \\
\hline Energy $b$ & & & - & - & - & - \\
\hline Textile fibres, minerals, etc. ${ }^{\mathrm{c}}$ & & & 0.35 & 0.04 & 0.09 & 0.07 \\
\hline Manufactures d+e & & & 0.13 & 0.14 & 0.29 & 0.40 \\
\hline Based on natural resources ${ }^{\mathrm{d}}$ & & & 0.55 & 0.49 & 0.86 & 0.91 \\
\hline Not based on natural resources ${ }^{\mathrm{e}}$ & & & 0.09 & 0.12 & 0.26 & 0.37 \\
\hline Others $\mathrm{f}$ & & & 0.82 & 0.99 & 0.59 & 0.38 \\
\hline \multicolumn{7}{|l|}{ II. Contribution (export structure of Dominican Republic } \\
\hline in this market) & & & 100.0 & 100.0 & 100.0 & 100.0 \\
\hline Natural resources ${ }^{a+b+c}$ & & & 65.5 & 46.0 & 20.8 & 12.5 \\
\hline Agriculture ${ }^{a}$ & & & 62.5 & 45.8 & 20.4 & 12.3 \\
\hline Energy $b$ & & & - & - & - & - \\
\hline Textile fibres, minerals, etc. ${ }^{\mathrm{c}}$ & & & 3.0 & 0.2 & 0.4 & 0.2 \\
\hline Manufactures ${ }^{d+e}$ & & & 26.5 & 41.2 & 72.9 & 84.2 \\
\hline Based on natural resources ${ }^{\mathrm{d}}$ & & & 9.6 & 8.1 & 11.4 & 9.4 \\
\hline Not based on natural resources ${ }^{\mathrm{e}}$ & & & 16.9 & 33.0 & 61.5 & 74.8 \\
\hline Others ${ }^{f}$ & & & 7.9 & 12.8 & 6.3 & 3.3 \\
\hline III. 10 main exports of Dominican Republic to this market & $\mathrm{g}$ & $\mathrm{h}$ & 44.8 & 46.1 & 66.1 & 73.6 \\
\hline 842 Outer garments, men's and boys', of textile fabrics & $*$ & + & 1.1 & 5.4 & 13.5 & 17.4 \\
\hline 846 Undergarments, knitted & $*$ & + & 4.6 & 5.6 & 8.2 & 12.5 \\
\hline \multicolumn{7}{|l|}{843 Outer garments, women's and girls', of textile fabrics } \\
\hline or crocheted & $*$ & + & 2.2 & 5.8 & 10.2 & 10.7 \\
\hline 612 Manufactures of leather, parts of footwear, etc. & & + & 1.2 & 3.4 & 6.3 & 6.5 \\
\hline 872 Medical instruments and appliances, n.e.s. & & + & 0.2 & - & 4.3 & 6.5 \\
\hline 845 Outer garments, other articles, knitted/crocheted & $*$ & + & 0.7 & 0.9 & 4.7 & 5.5 \\
\hline 772 Electrical apparatus for making and breaking elec. circuits & $*$ & + & 0.7 & 1.3 & 3.9 & 4.1 \\
\hline 061 Sugar and honey & & - & 32.3 & 17.8 & 7.2 & 4.0 \\
\hline 897 Jewellery, goldsmiths' and silversmiths' wares, etc. & $*$ & + & 0.1 & 3.7 & 4.8 & 3.8 \\
\hline 844 Undergarments, textile fabrics (not knitted/crocheted) & $*$ & + & 1.9 & 2.2 & 3.0 & 2.6 \\
\hline
\end{tabular}

${ }^{\mathrm{a}}$ Sections 0, 1 and 4 ; divisions 21, 22, 23, 24, 25 and 29 of the Standard International Trade Classification (SITC Rev2).

${ }^{\mathrm{b}}$ Section 3 .

${ }^{c}$ Divisions 26, 27 and 28

${ }^{\mathrm{d}}$ Divisions 61, 63 and 68; groups 661, 662, 663, 667 and 671.

${ }^{\mathrm{e}}$ Sections 5, 6 (minus the divisions and groups mentioned in $\mathrm{d}$ ), 7 and 8 .

f Section 9.

g Groups which correspond to the 50 most dynamic ones (*) in this market during 1980-1995.

${ }^{\mathrm{h}}$ Groups in which the market share increased (+) or decreased (-) during 1980-1995.

from natural resource-based $(65.5 \%$ of total exports in 1980$)$ to manufactures-based $(84.2 \%$ of the total in 1995). Manufactures not based on natural resources became the strong suit in the Dominican export repertoire, accounting for three-quarters $(74.8 \%)$ of all exports to the North American market in 1995. Almost three-quarters (73.6\%) of Dominican exports were concentrated in just 10 product groups at the three-digit level of SITC-Rev.2 in 1995. The Dominican Republic was gaining market share in nine of those ten groups, and seven of the products corresponded to the group of the fifty most dynamic items in the North American market. Half of these principal export items pertain to the apparel industry and their share increased from $10.5 \%$ of total exports in 1980 to $48.7 \%$ in 1995 . Without doubt, the apparel industry is by far the principal link between the Dominican and the North American markets and should therefore represent the extension of the national industrialization process into the international market.

Table 3 presents similar information for Costa Rica, which also improved its import market share in the North American market (from 0.15\% to $0.23 \%$ between 1980 and 1995). This improvement was cen- 
TABLE 3

Costa Rica: Aspects of its international competitiveness

in the North American market

\begin{tabular}{|c|c|c|c|c|c|c|}
\hline & & & 1980 & 1985 & 1990 & 1995 \\
\hline I. Share of North American import market & & & 0.15 & 0.15 & 0.19 & 0.23 \\
\hline Natural resources ${ }^{a+b+c}$ & & & 0.31 & 0.45 & 0.48 & 0.61 \\
\hline Agriculture $^{\mathrm{a}}$ & & & 1.20 & 1.17 & 1.25 & 1.36 \\
\hline Energy ${ }^{b}$ & & & - & 0.01 & - & - \\
\hline Textile fibres, minerals, etc. ${ }^{\mathrm{c}}$ & & & 0.03 & 0.05 & 0.02 & 0.04 \\
\hline Manufactures $^{\mathrm{d}+\mathrm{e}}$ & & & 0.03 & 0.06 & 0.12 & 0.16 \\
\hline Based on natural resources ${ }^{\mathrm{d}}$ & & & 0.03 & 0.04 & 0.07 & 0.06 \\
\hline Not based on natural resources ${ }^{\mathrm{e}}$ & & & 0.03 & 0.06 & 0.13 & 0.16 \\
\hline Others ${ }^{\mathrm{f}}$ & & & 0.07 & 0.04 & 0.08 & 0.11 \\
\hline \multicolumn{7}{|l|}{ II. Contribution (export structure of Costa Rica } \\
\hline in this market) & & & 100.0 & 100.0 & 100.0 & 100.0 \\
\hline Natural resources ${ }^{a+b+c}$ & & & 85.2 & 71.0 & 49.6 & 41.8 \\
\hline Agriculture $^{\mathrm{a}}$ & & & 84.8 & 70.1 & 49.5 & 41.6 \\
\hline Energy ${ }^{b}$ & & & - & 0.5 & - & - \\
\hline Textile fibres, minerals, etc. ${ }^{\mathrm{c}}$ & & & 0.4 & 0.5 & 0.2 & 0.2 \\
\hline Manufactures ${ }^{\mathrm{d}+\mathrm{e}}$ & & & 13.5 & 28.1 & 49.1 & 56.6 \\
\hline Based on natural resources ${ }^{\mathrm{d}}$ & & & 1.0 & 1.2 & 1.4 & 1.1 \\
\hline Not based on natural resources ${ }^{\mathrm{e}}$ & & & 12.5 & 27.0 & 47.7 & 55.5 \\
\hline Others ${ }^{\mathrm{f}}$ & & & 1.3 & 0.8 & 1.3 & 1.6 \\
\hline III. 10 main exports of Costa Rica to this market & g & $\mathrm{h}$ & 78.4 & 74.0 & 73.0 & 72.6 \\
\hline 057 Fruit and nuts (not oil nuts), fresh or dried & & + & 34.4 & 34.1 & 27.2 & 24.3 \\
\hline 846 Undergarments, knitted or crocheted & $*$ & + & 5.2 & 5.0 & 9.9 & 12.6 \\
\hline 842 Outer garments, men's and boys', of textile fabrics & $*$ & + & 0.5 & 3.7 & 9.7 & 11.6 \\
\hline 844 Undergarments, textile fabrics (not knitted/crocheted) & $*$ & + & 0.1 & 2.0 & 2.9 & 4.6 \\
\hline 071 Coffee and coffee substitutes & & + & 17.6 & 12.5 & 6.0 & 4.1 \\
\hline 845 Outer garments, other articles, knitted/crocheted & $*$ & + & 0.3 & 0.6 & 3.1 & 4.0 \\
\hline 843 Outer garments, women's and girls', of textile fabrics & $*$ & + & 2.6 & 5.4 & 6.8 & 3.5 \\
\hline 897 Jewellery, goldsmiths' and silversmiths' wares, etc. & $*$ & + & - & 0.4 & 1.2 & 2.7 \\
\hline 011 Meat and edible meat offals, fresh, chilled or frozen & & - & 17.0 & 9.3 & 4.7 & 2.6 \\
\hline 054 Vegetables, fresh, chilled, frozen or simply preserved & & + & 0.8 & 1.0 & 1.6 & 2.5 \\
\hline
\end{tabular}

${ }^{a}$ Sections 0, 1 and 4; divisions 21, 22, 23, 24, 25 and 29 of the Standard International Trade Classification (SITC Rev2).

${ }^{\mathrm{b}}$ Section 3.

${ }^{\mathrm{c}}$ Divisions 26, 27 and 28.

d Divisions 61, 63 and 68; groups 661, 662, 663, 667 and 671.

e Sections 5, 6 (minus the divisions and groups mentioned in d), 7 and 8 .

${ }^{\mathrm{f}}$ Section 9.

${ }^{\mathrm{g}}$ Groups which correspond to the 50 most dynamic ones (*) in this market during 1980-1995.

${ }^{\mathrm{h}}$ Groups in which the market share increased (+) or decreased (-) during 1980-1995

tered on both agricultural products $(0.31 \%$ to $0.61 \%)$ and manufactures $(0.03 \%$ to $0.16 \%)$. During this period, the export structure of Costa Rica was transformed from one heavily based on natural resources (85.2\% of total exports in 1980) to one in which manufactures came to represent the larger part (56.6\% in 1995). Manufactures not based on natural resources accounted for $55.5 \%$ of all exports to North America in that year. Three-quarters of Costa Rica's total exports correspond to products in the top ten, and half of those export items are from the apparel industry, which accounts for five of the six items among the 50 most dynamic North American im- ports. The share of apparel in Costa Rica's total exports to the North American market jumped substantially (from $8.7 \%$ in 1980 to $36.3 \%$ in 1995). Costa Rica gained market share in nine of these ten items. Again, apparel was the principal link between the Costa Rican and North American markets and presumably represented the extension of the Costa Rican industrialization process into the international market.

These countries are representative of the general situation in the Caribbean Basin: small countries which have, to different degrees, wagered on the apparel segment of the North American market. Their 
apparel exports go solely to that market, suggesting that either they are not plentiful enough to be spread around or they are not competitive enough to enter other markets. As we shall see, the manner in which these countries supply the North American market determines to a large extent the impact that the apparel industry has on the growth and development trajectories of the Caribbean Basin countries.

\section{IV}

\section{The North American apparel connection}

Gereffi (1997) has demonstrated that the nature of the apparel marketing chain has changed considerably over time. Buyer-driven chains have progressively supplanted producer-driven chains: that is to say, companies that buy apparel (usually by contracting out fashion articles of their own design) for sale to their up-market clientele are increasingly calling the shots in the United States industry compared to companies that produce standard clothing for distribution to retailers. In the United States market, large retail stores (such as Sears, Wal-Mart, J.C. Penney, K-Mart, etc.) and branded marketers (such as Liz Claiborne, Donna Karan, Polo, Tommy Hilfiger, Nike, etc.) have come to possess greater influence over the whole chain itself (Gereffi and Korzeniewicz (eds.), 1994, pp. 95-122).

As was also suggested by Gereffi (1997, pp. 16-31), this evolution allowed "full package" suppliers from developing countries in East Asia (i.e., those who provide the complete article required by the buyers) to play a more important role, cutting the United States clothing producers out of the relationship. This strengthened the position of the East Asian domestic companies capable of organizing the complete production of the article, and such companies capable of providing all the organization necessary to convert retailers' or branded marketers' designs into finished products which met the buyers' required volumes on time as well as fulfilling their quality standards became significant competitive forces in the apparel industry, particularly in women's wear. Moreover, they also provide a strong boost to the national growth and development trajectory.

East Asian full package suppliers from Taiwan, Hong Kong and South Korea did this by establishing their own regional production systems which organized integrated production from textiles and cloth through the apparel assembly process to final delivery to the retailers or branded marketers. Some even developed into international competitors of their original clients. This gave a significant impulse to their domestic economies. Although these countries appear to be losing import market shares in the OECD market, in fact, their apparel companies often export their products from overseas factories that assemble components from the home country of the Asian manufacturers/traders, so that although their market shares in final markets for direct apparel exports decline, their exports of textile and cloth inputs to offshore assembly sites (such as China, Thailand, Indonesia, etc.) rise. Thus, in Asia, full package suppliers in Taiwan, South Korea and Hong Kong have developed their own networks of assembly operations in other parts of Asia, where full package suppliers and simple assembly operations for export coexist.

The situation is considerably different for apparel production in Latin America (essentially Mexico and the Caribbean Basin). The apparel companies operating there tend to be subsidiaries of branded manufacturers (especially for women's underwear) or foreign or national companies which compete for inbond assembly contracts (mostly for men's outerwear) from the overseas buyers of the large United States retailers and which do not provide full package services. In this case, full package suppliers have not arisen because the competitive advantages stem strictly from locating the final assembly stage in those countries, primarily in order to take advantage of lower wages. The overseas buyers, or the branded manufacturers themselves, handle all the other aspects of the package. Thus, simplifying somewhat, one can distinguish two different realities in the apparel industry of developing country suppliers of the OECD market. One is an Asian version in which local companies of the East Asian NICs act as full package suppliers (mostly of women's wear) to large retailers and branded marketers. The other is a Latin American version which isolates the assembly process in 
those countries, mainly for the supply of women's underwear through subsidiaries of branded manufacturers or of men's outerwear via foreign or national subcontractors to overseas buyers. The Asian "full package" manufacturer/trader version is in stark contrast with what could be called the Caribbean Basin "special access-export processing zone-low wage" version. These differences are of central importance for defining the local impact in terms of national growth and development.

The North American apparel connection has been responsible for the huge increase in apparel exports from Latin America. Textile and apparel exports from Latin America to the United States market grew from US\$3.4 billion (12\% of total United States imports of such) in 1990 to US\$14.5 billion (27\%) in 1997 (14.2\% originated in the Caribbean Basin and $11 \%$ came from Mexico during 1997). ${ }^{3}$ Latin American countries were gaining ground as apparel suppliers to the United States market, but they were doing so in a very different way from their East Asian competitors.

The original Mexico/Caribbean Basin variant ${ }^{4}$ was considered to have special access because it rested heavily on the so-called "production sharing" mechanism of the United States tariff code. This HTS 9802 provision allows United States-sourced apparel inputs to be assembled offshore, paying tax upon re-entry into the United States market solely on the value added (mainly wages) outside the country. The share of United States textile and clothing imports made under this scheme has risen from US\$1.4 billion (6\% of all such imports) in 1987 to US\$8.9 billion $(21 \%)$ in 1997 . Mexico (37\% of the apparel imports via HTS 9802) and the Caribbean Basin (56\% of such imports) together provide over $90 \%$ of textile and apparel imports into the United States via this mechanism (United States International Trade Commission, 1997a). In sharp contrast with the Asian countries, a very substantial proportion of all Latin American exports to the United States entered under the HTS 9802 mechanism in 1996: Mexico (37.6\%), Dominican Republic $(58.7 \%)$, Costa Rica $(35.4 \%)$, Honduras (54.6\%), Guatemala (34.2\%), El Salvador (62.1\%)

\footnotetext{
3 Figures from United States International Trade Commission, 1998.

${ }^{4}$ Since the inception of the North American Free Trade Area in 1994 the first signs of full package suppliers, mostly United States companies, have appeared in Mexico. See Gereffi and Bair (1998), pp. 26-35.
}

and Jamaica (53.6\%). It is in this sense that one can speak of "special access" for apparel from Mexico and the Caribbean Basin.

These Latin American countries also made increasing use of export processing zones (EPZs) to give incentives to the assembly trade related to the HTS 9802 mechanism. Between 1980 and 1992, for example, the importance of EPZ operations in total exports rose from $11 \%$ to $68 \%$ in the case of the Dominican Republic, from $16 \%$ to $41 \%$ for Mexico, and from virtually nothing to $21 \%$ in Costa Rica (Willmore, 1996). The EPZs provide total tax exemption for imports of inputs and components and exports of final products, and total or temporary exemption from income, profit and profit remittance taxes. Complementary aspects include the provision of facilities in terms of foreign exchange operations, limited access to the domestic market and expedite customs service. The EPZ facilities and tax exemptions represent the national counterpart to the United States HTS 9802 mechanism intended to provide additional incentives for United States-based apparel firms to make use of assembly operations in the Caribbean Basin and Mexico.

The third element of the original Latin American variant of apparel exports to the United States market rested on low labour costs. Figure 4, for example, shows that after the massive devaluation of the na-

FIGURE 4

Dominican Republic: Ratio of labour costs to employment in the export processing zones

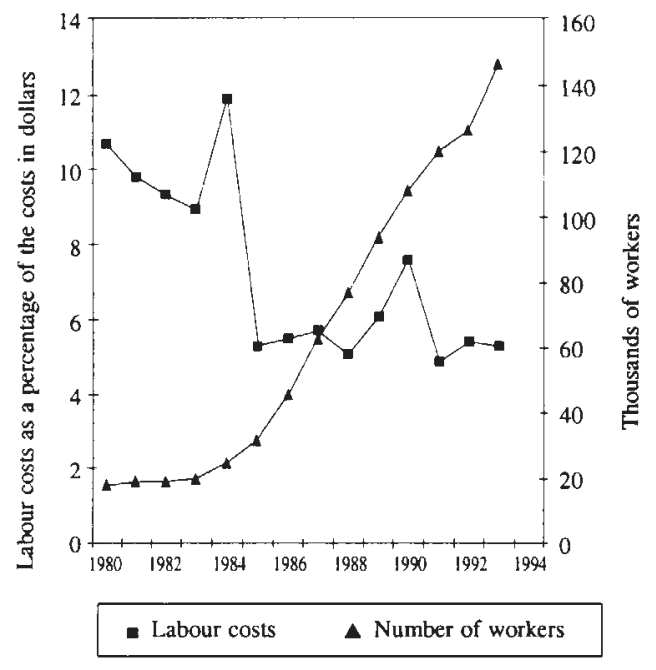

Source: Mortimore, Duthoo and Guerrero, 1995, p. 26. 
tional currency in the Dominican Republic in 1985 the relative wage costs there declined from the equivalent of $12 \%$ of those in the United States to a little over 5\%. At the same time employment in the EPZs exploded from less than 40,000 to about 150,000 in 1993. The lower wage rates (measured in dollars) resulting from the huge devaluation in 1985 (itself related to the external debt crisis) explain more than any other single factor why EPZs took off between 1986 and 1993. For example, the number of EPZs in the Dominican Republic grew from 8 to 30, the number of companies installed in them jumped from 168 to 447, the gross value of exports shot up from US\$246.2 to US\$1,250 millions, and the value of net foreign exchange earnings from those zones soared from US\$88.4 to US\$368.5 million (Reyes and Domínguez, 1993). This was a very significant factor in the recuperation of the economy of the Dominican Republic, since its other exports (mostly natural resources) had entered into a secular nose dive, falling from about US\$900 million in 1984 to only about US $\$ 500$ million in 1993, while those from the EPZs rocketed from US $\$ 200$ to about US $\$ 1,250$ million over the same period (Mortimore, Duthoo and Guerrero, 1995).

Thus, the example of the Dominican Republic poignantly captures the relationship between the special access to the United States market, the use of EPZs and the low wages which characterize the Caribbean Basin variant, and its wildly increased exports of apparel to the United States market. Unfortunately, this variant also has its costs.

\section{V \\ The down side of the special access-EPZ-low wage variant in the Caribbean Basin}

Each one of the components of the Caribbean Basin variant for apparel exports to the United States suffers from severe deficiencies as regards its ability to help these small countries to "make it" into the winners' circle.

First, special access represents a direct challenge to the national industrialization process. The very nature of the HTS 9802 mechanism penalizes practically all value added outside of the United States. This limits its use to activities in which low wages are prominent (and compensate for the United States duty on value added) and in which local physical inputs are neither needed nor desired by the manufacturer or buyer. It is extremely difficult for the national government of the assembling country to implement policies that effectively promote greater local integration of the industry. That is the case for both higherlevel training of the workforce, which would eventually command higher wages for more skilled and complex work, and for the incorporation of local suppliers of inputs such as thread and buttons: let alone major inputs such as cloth or cutting operations. Thus, the HTS 9802 mechanism tends to trun- cate the industrialization process itself, making use only of the assembly operation in the Caribbean Basin, to the detriment of any integrated national industrialization process in the assembly country.

Another weak point in the special-access relationship between the Caribbean Basin and the United States market has to do with what are known as "calls" in United States legislation. A United States firm which feels that it has been unduly affected by what might be considered an abnormal increase in imports into the United States can request a decision by the United States Department of Commerce to determine if import disruption has taken place. The Department of Commerce can issue "calls" (warnings) to the local textile offices that allocate quotas in exporting countries in order to restrain the growth of such items. This occurred, for example, in March of 1995 when calls were issued to Caribbean Basin producers of underwear and pyjamas (some of the more important apparel exports of the region). While most assemblers of these items bowed to the United States demands, Costa Rica - which was one of the countries hardest hit by this measure- took the case to the 
World Trade Organization and won, although the damage done to Costa Rican underwear and pyjama exports was not compensated. In this sense, special access is sometimes less special than it appears for the countries involved.

Another problem associated with special access is that some assembly countries become more special than others. For example, the implementation of the North American Free Trade Agreement (NAFTA) in 1994 effectively gave Mexico advantages that the Caribbean Basin countries did not possess. Mexico enjoyed a six point tariff rate advantage in the United States market, was no longer subject to import quotas on many apparel items and, most notably, could count Mexican inputs as part of the requisite NAFTA content, thus giving it a huge advantage over the Caribbean Basin countries. For that reason, since the inception of NAFTA the apparel assemblers of the Caribbean Basin have been lobbying the United States Congress in search of "NAFTA parity" for their apparel exports. Thus, not all assemblers are special in the same way.

There are also deficiencies in respect of the export processing zone mechanism, which is the local counterpart to the HTS 9802 mechanism. The intense interest of Caribbean Basin countries in developing new exports in the context of the debt crisis of the 1980 s and the structural decline of natural resource exports led them to enter into "incentives wars" for foreign direct investment (Mortimore and Peres, 1997). This competition was so severe that the level of incentives granted came to signify that huge assembly operations accounting for $40 \%$ or more of these countries' whole exports to the United States provided virtually no fiscal income for the local government. Moreover, as a result of competitive pressures, incentives which were intended to be temporary (8-12 years) became renewable and, in practice, endless. Thus, in the heat of the battle to attract FDI to local EPZs, many governments give away as incentives virtually all of the potential fiscal income that could be derived from such activities. These lost resources could have been used to strengthen the local industrialization process or to promote other exports or improve the international competitiveness of the national economy through investments in infrastructure (ports, airports, roads) and basic (electricity, water) and other services (telecommunications, financial services, etc.). Rather than representing a starting point for many industries, as was the case for some of the East Asian NICs, EPZs became an end in themselves that eventually came to limit and distort the nascent industrialization process of many of these Latin American countries.

Finally, the low-wage element of the Caribbean Basin variant of apparel exports to the United States has also demonstrated very significant deficiencies. More than ten years after the massive national currency devaluations of the 1980s, the labour costs (including social and fringe benefits) in the apparel industry of the Caribbean Basin countries have been rising steadily (measured in dollars). This translates into pricing many of their apparel assembly operations out of the market, without any real manifestation of industrial upgrading or specialization in higher-value output. Table 4 presents labour cost data for forty apparel producers during 1990-1995, ordered from highest (Switzerland, Japan and Germany had hourly labour costs over US\$ 20 in 1995) to lowest (five Asian countries, including China, had hourly labour costs of under US\$ 0.30 in the same year). The Caribbean Basin countries are generally in the middle of the pack (ranging from positions 13 to 24). All of the Caribbean Basin countries had significant increases in their hourly labour costs during 1990-1995: Costa Rica's costs went up from US\$ 1.09 to US\$ 2.23; Jamaica, from US\$ 0.91 to US\$ 1.55; El Salvador, from US\$ 0.69 to US\$ 1.43; and Guatemala, from US\$ 0.45 to US\$ 1.30. In other words, labour costs in the Caribbean Basin are increasing faster than in most other areas and are substantially higher than many of the assemblers of standard apparel in Asia. Even within the Caribbean Basin, there is a considerable distance between higher cost Costa Rica and lower cost Guatemala. This suggests that as the level of competition in this industry increases in keeping with the demise of the Multifibre Agreement perhaps these countries may be tempted to follow a strategy of competitive devaluations of their national currencies in order to artificially prolong the life of their apparel exports. But that would only make matters worse.

A more fundamental concern is that the current Caribbean Basin variant of exporting apparel to the United States market simply does not meet the requirements of the stylized view of the growth of countries presented in Section I. It is evident that apparel assembly in the Caribbean Basin resulted in 
TABLE 4

Labour costs in the apparel industry, 1990-1995

\begin{tabular}{|c|c|c|c|c|c|}
\hline \multirow{2}{*}{ Rank } & \multirow{2}{*}{ Country } & \multicolumn{3}{|c|}{ Hourly costs in US\$ ${ }^{a}$} & \multirow{2}{*}{$\begin{array}{l}1990-1995 \\
\text { annual growth } \\
\text { rate }(\%)\end{array}$} \\
\hline & & 1990 & 1993 & 1995 & \\
\hline 1 & Switzerland & 14.19 & 18.08 & 22.42 & 9.6 \\
\hline 2 & Japan & 6.34 & 10.64 & 20.95 & 27.0 \\
\hline 3 & Germany & 7.23 & 17.22 & 20.35 & 23.0 \\
\hline 4 & Italy & 12.50 & 12.31 & 13.68 & 1.8 \\
\hline 5 & United States & 6.56 & 8.13 & 9.62 & 8.0 \\
\hline 6 & Spain & 7.08 & 6.41 & 7.78 & 1.9 \\
\hline 7 & Greece & 4.33 & 5.85 & 7.19 & 10.7 \\
\hline 8 & Taiwan & 3.41 & 4.61 & 5.18 & 8.7 \\
\hline 9 & Hong Kong & 3.05 & 3.85 & 4.32 & 7.2 \\
\hline 10 & Singapore & 2.43 & 3.06 & 4.01 & 10.5 \\
\hline 11 & Portugal & 2.30 & 3.03 & 3.85 & 10.9 \\
\hline 12 & South Korea & 2.46 & 2.71 & 3.29 & 6.0 \\
\hline 13 & Costa Rica & 1.09 & 1.08 & 2.23 & 15.4 \\
\hline 14 & Hungary & 0.92 & 1.62 & 1.68 & 12.8 \\
\hline 15 & Mexico & 0.92 & 1.08 & 1.61 & 11.8 \\
\hline 16 & Malaysia & 0.56 & 0.77 & 1.59 & 23.2 \\
\hline 17 & South Africa & 1.07 & 1.12 & 1.58 & 8.1 \\
\hline 18 & Czech Republic & 2.79 & 1.29 & 1.55 & -11.1 \\
\hline 19 & Jamaica & 0.91 & 0.78 & 1.55 & 11.2 \\
\hline 20 & Turkey & 1.35 & 3.29 & 1.52 & 2.4 \\
\hline 21 & Dominican Republic & 0.67 & 0.63 & 1.52 & 17.8 \\
\hline 22 & El Salvador & 0.69 & 0.63 & 1.43 & 15.7 \\
\hline 23 & Poland & 0.50 & 0.44 & 1.42 & 23.2 \\
\hline 24 & Guatemala & 0.45 & 0.78 & 1.3 & 23.6 \\
\hline 25 & Mauritius & $\ldots$ & 1.04 & 1.28 & \\
\hline 26 & Morocco & 0.92 & 1.06 & 1.22 & 5.8 \\
\hline 27 & Thailand & 0.63 & 0.71 & 1.11 & 12.0 \\
\hline 28 & Philippines & 0.46 & 0.53 & 0.72 & 9.4 \\
\hline 29 & Egypt & 0.34 & 0.43 & 0.51 & 8.4 \\
\hline 30 & Zimbabwe & $\ldots$ & 0.35 & 0.45 & $\ldots$ \\
\hline 31 & Sri Lanka & 0.24 & 0.35 & 0.41 & 11.3 \\
\hline 32 & Kenya & 0.47 & 0.23 & 0.34 & -6.3 \\
\hline 33 & Indonesia & 0.16 & 0.28 & 0.33 & 15.6 \\
\hline 34 & India & 0.33 & 0.27 & 0.29 & -2.6 \\
\hline 35 & Pakistan & 0.24 & 0.27 & 0.29 & 3.9 \\
\hline 36 & Vietnam & $\ldots$ & 0.26 & 0.29 & $\ldots$ \\
\hline 37 & China & 0.26 & 0.25 & 0.25 & -0.8 \\
\hline 38 & Nigeria & 0.2 & 0.27 & 0.24 & 3.7 \\
\hline 39 & Bangladesh & $\ldots$ & 0.16 & 0.20 & $\ldots$ \\
\hline 40 & Tanzania & $\ldots$ & 0.18 & $\ldots$ & $\ldots$ \\
\hline
\end{tabular}

Source: Werner International, Apparel Hourly Labor Cost, New York, 1996, cited in Lall and Mortimore, 1997.

${ }^{a}$ Costs include social and fringe benefits.

an impressive explosion of apparel exports. However, given the characteristics of the particular way this was achieved, this phenomenon did not represent an intensification of the national industrialization processes (on the contrary, it truncated them). These exports do not represent the extension of the national apparel industry into the international market, but simply the localization of the assembly function itself. As a consequence, this process does not create national leader companies. There is no transformation of the industry such that the assembler country extends its industrialization into the more technologically complex or more fashion-centric aspects of the apparel industry. 


\section{VI}

\section{The example of Costa Rica}

Costa Rica's apparel exports to the United States market increased steadily until 1995, when they declined by over $7 \%$, falling from US\$ 776.3 million in that year to US\$ 710.0 million in 1996 (United States International Trade Commission, 1997b). Costa Rica saw its apparel exports decline in four of the five principal apparel categories (at three digits of the Harmonized Tariff System) that together accounted for over half such exports:

- $\quad$ HTS 347 - cotton men's trousers (from US\$ 156.6 to US\$ 148.2 million),

- $\quad$ HTS 352 - cotton underwear (from US\$ 112.2 to US\$ 77.1 million),

- $\quad$ HTS 649 - synthetic fibre brassières (from US\$ 84.7 to US\$ 60.4 million), and

- $\quad$ HTS 338 - synthetic fibre underwear (from US\$ 51.5 to US\$ 45.3 million).

The Costa Rican apparel industry apparently had developed wrinkles.

A detailed analysis of ten of the principal export items of this industry in 1994 (at six digits of the HTS) revealed that by 1996 each item had lost import market shares, on average by $23.6 \% .^{5}$ While Latin American countries were winning United States import market shares for these same items, Costa Rica was losing out, primarily to Mexico and Central American countries such as Honduras, El Salvador and Guatemala, but not to the Dominican Republic. Was Costa Rica being priced out of the market? An in-depth study of the international competitiveness of the Costa Rican apparel industry was carried out to respond to that concern (Mortimore and Zamora, 1998). A formal questionnaire was administered to 16 firms in the sector, and the information from the interviews and analysis of results of the questionnaire threw light on the specific competitive situations of these enterprises.

The sixteen firms could be classified into three different groups:

5 Calculated using the MAGIC computer programme, which measures international competitiveness in terms of import market shares in the United States market at up to 10 digits of the HTS. Available from the ECLAC Subregional Headquarters in Mexico. Contact rbuitela@un.org.mx.
Group I: Very large subsidiaries of United States TNCs assembling undergarments for export to the United States market via HTS 9802, which faced "calls" in 1995 after having improved their international market shares considerably during 1990-1995. They accounted for the lion's share of Costa Rica's apparel exports to the United States. An indicator of their success, aside from their domination of Costa Rican clothing exports, is that their employment doubled between 1985 and 1990 and doubled again between 1990 and 1995. Examples are the subsidiaries of large United States branded manufacturers such as Hanes (Sara Lee), Warnaco and Lovable.

Group II: Other, mostly new, foreign subsidiaries which mainly assemble clothing subject to quotas in the United States market, which they access via HTS 9802, and which had a less successful performance in general during 1990-1995. This group accounts for an appreciable portion of the remaining Costa Rican clothing exports and its employment levels rose by $50 \%$ between 1985 and 1990 and by about $40 \%$ between 1990 and 1995. They employ fewer personnel than the companies in Group I and are also less dynamic. Examples are the subsidiaries of United States firms such as Tropical Sportswear, Cluett Peabody, Todd Uniform and Gilmour Trading.

Group III: Old-established national firms, mostly small ones using the export contract regime which accessed the United States market via non-HTS mechanisms and have had some success in improving their international market shares. Their exports are not significant in the context of the Costa Rican clothing industry. While the employment of these companies doubled between 1985 and 1990, it fell by one-third between 1990 and 1995. Their domestic market shares have been collapsing due to increased import competition. Examples include the Cia. Textil Centroamericana, El Acorazado, Tejidos El Aguila, etc.

Given their different competitive situations, these companies also had different corporate strategies. Group I firms, which possessed more sophisticated, specialized operations in which quality is extremely important, had set up integrated regional 
production systems in the Caribbean Basin some time ago. Typically, they had subsidiaries in 4 or 5 different sites, such as the Dominican Republic, Jamaica, Honduras, El Salvador and Mexico, as well as Costa Rica. In this fashion, they could adapt to changing national competitive situations (labour costs, exchange rate variations, and other changed circumstances) by adding/dropping lines of production in particular sites. They had no need to be "footloose". Generally they assembled apparel products for their headquarters firm which sold the output to retailers in the United States market. Their success in Costa Rica allowed them to implement "expansive" strategies until the 1995 "calls" were made.

Group II enterprises had less sophisticated, less specialized operations, and wages rather than quality was considered to be the principal element in their international competitiveness. In this sense they had more of a strict "cost centre" mentality. They tended to have much smaller corporate networks in the Caribbean, based on only 1 or 2 main sites. They were more "footloose" and prone to adapt to changing national competitive situations by moving away when the going got rough. Rather than producing for their headquarters corporation itself, these firms generally competed for the assembly portion of buyers' contracts, often delivering the product directly to the contractor. Given their more limited success, their strategies tended to be more neutral than expansive.

Group III companies were the least sophisticated and least specialized of the three groups. These national firms considered foreign technology to be the principal element of their competitiveness both in Costa Rica and in the international market. They possessed no international corporate network to speak of and were, effectively, at the mercy of the national competitive situation. Because of the collapse of their domestic market shares due to import liberation, these companies were obliged to compete increasingly for the assembly portion of buyers' contracts in the international market in order to survive. Their strategies can be considered defensive.

The most interesting finding of this empirical study in Costa Rica is that these three different groups of firms which implemented different corporate strategies all provided some exceptionally negative indications of the problems associated with the special access/export processing zone/low wage formula for exporting apparel to the United States market from Costa Rica. For example, one of the parent firms -a major United States branded manufacturer owning two of the five large Group I firms in Costa Rica (and others in the Dominican Republic, Mexico, and more recently other Central American countries)- announced that it was to be restructured (selling off its United States yarn and textile operations). It would therefore no longer manufacture many of the goods that it sells. What does that forebode for the relatively high-cost plants in Costa Rica? Closure? Sale? Hopefully, it will not follow the example of its arch-rival, Fruit of the Loom. ${ }^{6}$ Another example is a Group I firm which closed one of its three plants in Costa Rica only to expand activities in neighbouring Panama. In 1996 a Group II company simply disappeared from Costa Rica, leaving behind huge outstanding liabilities, especially in respect of wages and social security payments. Workers claimed that there was no advance warning of this "fly-by-night" exit over the weekend. Will more follow this example as Costa Rica's international competitiveness in this industry wanes? A final example has to do with a Group III enterprise. In 1996 one of the four national companies, owned by a prominent local businessman (then President of the National Manufacturers' Association), that attempted to survive by competing for export assembly contracts simply went broke due to the increasing competitive pressures.

What does all this mean? At the very least, it would seem to suggest that the problems of apparel exports via the special access/export processing zone/low wage mechanism would appear to be systemic. They do not relate to any particular kind of firm with any particular corporate strategy: rather, all apparel firms see their international competitiveness crumble. If one were to prepare a kind of Costa Rican scorecard on the capacity for the apparel industry to propel the country towards "the winners' circle" mentioned in Section I, some interesting conclusions can be drawn about this experience. First, in terms of intensifying the national industrialization process, the reliance on the HTS 9802 mechanism does indeed

\footnotetext{
${ }^{6}$ Fruit of the Loom has been imploding: laying off 16,355 of its 29,112 United States workers since 1994, suffering operating losses of US\$ 283 million in 1997, and provoking complaints of poor service from key clients, such as Wal-Mart Stores Inc. and Kmart Corp. The solution proposed by its CEO is to move its domicile to the Cayman Islands to save on taxes. See Business Week, 1998, pp. 50-54.
} 
truncate the national industrialization process in respect of apparel. Only the assembly stage is located in the country and, aside from labour, no significant local inputs are incorporated into the final products. Moreover, the tax incentives for the export processing zones so limit the fiscal income received by the State from this central export activity that it cannot be said to provide resources for other urgent activities, which include stimulating the national industrialization process, promoting new exports, and improving the international competitiveness of the economy as a whole through the development of infrastructure, basic services, or indeed the training of human resources for more sophisticated and better-remunerated tasks.

Second, as regards extending the national industrialization process into the international market by way of exports of manufactures, it is abundantly clear that these apparel exports are not linked to the national economy in any integral way. These exports are "competitive" only in the United States market, and they cannot be directed to other markets when problems arise in that one, such as the "calls" on pyjamas and underwear in March 1995. In the particular case of Costa Rica, one could go so far as to say that the WTO dispute proved that the United States can be an extremely unpleasant trading partner when its nose is tweaked in international fora.

Finally, does the apparel industry in Costa Rica create leading national companies that evolve into major players in international markets? On the contrary, the opposite took place when the opening up of the economy gave rise to competition from imports that destroyed most of the ISI-based integrated operations of national firms. These firms do not possess a Caribbean network of assembly operations, thus they grow or decline in keeping with the evolution of the international competitiveness of the Costa Rican economy. Even their ability to compete for buyers' contracts is severely limited by the size and characteristics of the local economy, let alone their ability to manufacture (rather than assemble) apparel. They have a hard time surviving.

So, what makes apparel-based industrialization in the Caribbean Basin such a "threadbare garment"?

It takes place by way of a mechanism that is designed exclusively to make United States apparel firms more competitive in their own market (by taking advantage of low wages in the Caribbean). What is needed is one that explicitly and consciously aims at raising the long-term growth of the host economies, and especially at achieving the sustained rise in per capita income that will place them in the winners' circle.

Instead of deepening national industrialization it truncates it.

Instead of producing exports that represent the international extension of the industrialization process, it represents the simple assembly of foreign components, which is no more than a potential starting point for industrial activities.

Instead of giving birth to national companies which evolve into global competitors it threatens their very existence.

Clearly, when an activity which generates a major part of a country's exports does not serve to raise that economy to a higher level, closer to the goal of significant and sustained per capita income growth achieved by the winner countries, then apparel-based industrialization can justly be said to have become a "threadbare garment".

Dire consequences are foreseen for those apparel exporters that do not possess a local industrialization process when the Multifibre Arrangement comes to an end in 2005 under the terms of the Textile and Clothing Agreement of the Uruguay Round of GATT, for that is when the quotas placed on apparel by the United States and other countries are to be terminated. Caribbean apparel assemblers will face a difficult task to compete in the United States (or other markets) against the integrated apparel producers of East Asia. The latter produce textiles and apparel at scales of production far beyond the reach of the truncated Caribbean operations. Lacking a competitive local or subregional industrialization process to sustain apparel exports, most Caribbean operations will probably collapse in the face of the Asian steamroller.

In the few years remaining before that happens, the Caribbean Basin apparel industry can attempt to improve its situation. It must continue to insist on NAFTA parity in the North American market so that national or subregional local inputs can count as NAFTA inputs and thereby promote some degree of industrial integration. It must look for opportunities for associating in some way with the full package suppliers appearing in Mexico as a consequence of NAFTA. Finally, it must learn from the East Asian experience itself in terms of becoming full package suppliers. A stitch in time...

(Original: English) 


\section{Bibliography}

Audet, D. (1996): Globalisation in the clothing industry, in OECD (Organization for Economic Cooperation and Development), Globalisation of Industry: Overview and Sector Reports, Paris, OECD.

Business Week (1998): Strategies: A killing in the Caymans, New York, 11 May.

ESCAP (Economic and Social Commission for Asia and the Pacific) (1994): Transnational Corporations and Technology Transfer in Export Processing Zones and Science Parks, New York.

Gereffi, G. (1997): Global Shifts and Regional Response: Can North America Meet the Full Package Challenge?, Bobbin, San Francisco, California, Miller Freeman, Inc., November.

Gereffi, G. and J. Bair (1998): U.S. Companies Eye NAFTA's Prize, Bobbin, vol. 39, No. 7, San Francisco, California, Miller Freeman, Inc.

Gereffi, J. and M. Korzeniewicz (eds.) (1994): Commodity Chains and Global Capitalism, London, Praeger.

ILO (International Labour Organisation) (1996): Mundialización de las industrias del calzado, los textiles y el vestido, Geneva.

Lall, S. and M. Mortimore (1997): The garment industry in Dominican Republic, Costa Rica and Morocco, paper presented in the UNCTAD Research Project on Industrial Restructuring and International Competitiveness, Geneva, United Nations Conference on Trade and Development (UNCTAD), October.

Mortimore, M. (1997): La competitividad internacional: un CANalisis de las experiencias de Asia en desarrollo y América Latina, "Desarrollo Productivo" series, No. 40, Santiago, Chile, Economic Commission for Latin America and the Caribbean (ECLAC).

Mortimore, M., H. Duthoo and J. A. Guerrero (1995): Informe sobre la competitividad internacional de las zonas francas en la República Dominicana, "Desarrollo Productivo" series, No. 22, Santiago, Chile, ECLAC, August.
Mortimore, M. and W. Peres (1997): Policy competition for foreign direct investment in the Caribbean Basin: Costa Rica, the Dominican Republic and Jamaica, paper presented in the OECD Development Centre Research Project on Policy Competition and FDI, Paris, OECD, February.

Mortimore, M. and R. Zamora (1998): The International Competitiveness of the Costa Rican Clothing Industry, "Desarrollo Productivo" series, No. 46, Santiago, Chile, ECLAC.

Ramos, J. (1996): Industrial policy and competitiveness in open economies, "Desarrollo Productivo" series, No. 34, Santiago, Chile, ECLAC.

Reyes, F. and A. Domínguez (1993): Las zonas francas industriales en la República Dominicana: su impacto económico y social, Documento de trabajo, No. 73, Santo Domingo, Banco Central de la República Dominicana/ILO.

The Economist (1998): Little countries: small but perfectly formed, London, 3 January.

United States International Trade Commission (USITC) (1997a): Production Sharing: Use of U.S. Components and Materials in Foreign Assembly Operations, 1992-95, Washington D.C., December.

-(1997b): The Impact of the North American Free Trade Agreement on the U. S. Economy and Industries: A 3 Year Review, USITC investigation No. 332-381, Washington D.C.

- (1998): Annual Statistical Report on U.S. Imports of Textiles and Apparel: 1997, Washington, D.C., April.

van Liemt, G. (ed.) (1992): Industry on the Move. Causes and Consequences of International Relocation in the Manufacturing Industry, Geneva, International Labour Office/World Employment Programme.

Willmore, L. (1996): Export Processing in the Caribbean: Lessons from Four Case Studies, Working paper, No. 42, Santiago, Chile, ECLAC. 